\title{
Peptides Hydrolysate Derived from Collagen of Snakehead Murrel (Channa striata) Skin Demonstrate Anti-cholesterol and Anti- oxidant activities
}

\author{
Wenny Silvia L. Br. Sinaga ${ }^{1}$, Wangsa T. Ismaya ${ }^{2}$, Debbie S. Retroningrum ${ }^{3}$, Raymond R. Tjandrawinata ${ }^{2}$, Maggy T. \\ Suhartono ${ }^{1 *}$
}

${ }^{1}$ Department of Food Science, IPB University, Bogor, Indonesia

${ }^{2}$ Dexa Laboratories of Biomolecular Sciences, Cikarang, Indonesia

${ }^{3}$ School of Pharmacy, Institut Teknologi Bandung, Bandung, Indonesia

\section{ARTICLE INFO}

Article history:

Received May 22, 2019

Received in revised form February 2, 2020

Accepted February 20, 2020

\section{KEYWORDS:}

Anti-cholesterol, anti-oxidant,

bioactive peptide,

collagen,

collagenase,

snakehead murrel

\begin{abstract}
Anti-cholesterol and anti-oxidant play a crucial role to combat cardiovascular disease (CVD), due to formation of arterial plagues from oxidation of cholesterol. In the past decades, bioactive peptides demonstrating anti-cholesterol and antioxidant activities have emerged as the alternative drugs. In this study, acid soluble collagen was extracted from the skin of snakehead murrel and employed to induce secretion of collagenase by Bacillus licheniformis F11.4. The collagenases secreted were in turn used to produce peptides hydrolysate and were grouped in two distinct collagenase fractions, designated as fraction $D$ and F. Peptides hydrolysate produced by the fraction D was found to demonstrate HMG-CoA inhibitor activity comparable to pravastatin and limited anti-oxidant activity. Meanwhile, peptides hydrolysate generated using the fraction $F$ demonstrated anti-oxidant activity comparable to BHT ( $2 \mathrm{mM})$, vitamin $\mathrm{C}(2 \mathrm{mM})$, and vitamin $\mathrm{E}(2 \mathrm{mM})$, but limited HMG-CoA activity. Combination of the fraction $D$ and $F$ resulted in substantial HMG-CoA inhibition and anti-oxidant activities.
\end{abstract}

\section{Introduction}

Bioactive peptide (BP) is derived from proteins that are hydrolyzed by proteolytic enzymes (Korhonen and Pihlanto-Leppala 2006) or acid. BP has been developed into anti-hypertension, anti-oxidant, anti-thrombotic, and hypo-cholesterolemic drugs, which are powerful to prevent degenerative diseases, such as cardiovascular disease (CVD). Protein for the source of BP can be of plants, meat, milk (Korhonen and Pihlanto-Leppala 2003, 2006), and fish (Shahidi 1995; Senevirathne and Kim 2012). An example of anti-oxidative BP is lunasin, which is identified in soybean and other plants (Gálvez and de Lumen 1999). This peptide is already commercialized in the US and reported to decrease low density lipoprotein (LDL) and cholesterol in the blood (Gálvez 2012).

Recent studies have shown that anti-oxidative BP can be released from casein through enzymatic hydrolysis or during fermentation of milk using

\footnotetext{
* Corresponding Author

E-mail Address: mthenawidjaja@yahoo.com
}

protease-producing lactic acid bacteria (Korhonen and Pihlanto-Leppala 2003). The anti-oxidative BP displays free radical scavenging activities and inhibits enzymatic and non-enzymatic lipid peroxidation, most likely for being a preferred target over fatty acid free radicals (Rival et al. 2001). Consumption of anti-oxidative BP derived from goat is reported to show anti-atherogenicity by prolonging resistance of the lipoprotein fraction to oxidation (Kullisaar et al. 2006).

Snakehead murrel is one of the freshwater fishes from Channidae family with high collagen content in their skin. The skin of the fish has been considered as waste in the fish processing. In this study, we had extracted collagen from fish skin by acid treatment and found that the peptides hydrolysate derived from collagen was able to inhibit the activity of HMG-CoA reductase, the key enzyme for cholesterol biosynthesis. We also detected anti-oxidant activities with this peptides hydrolysate. The peptides were produced by proteolytic digestion using collagenases from $B$. licheniformis F11.4, a mutant 
of $B$. licheniformis from Indonesia. This bacterium has previously been shown as to demonstrate high proteolytic and collagenolytic activities (Waldeck et al. 2006), secreting collagenases of $124 \mathrm{kDa}$ and 26 $\mathrm{kDa}$ when grown in the presence of water-soluble collagen derived from milkfish skin (Baehaki et al. 2012; Baehaki et al. 2014). Our present study revealed the potential use of the peptides hydrolysate derived from the snakehead murrel skin acid soluble collagen as anti-cholesterol and anti-oxidant agents. This is the first report on the use of bioactive peptides hydrolysate derived from collagen of snakehead skin. Also, while most of marine bioactive peptides are developed as anti-hypertension agent, this report explored the possibility of application of marine bioactive peptides as anti-cholesterol and antioxidant instead. This report paves foundation for further identification of the bioactive peptides and structural-function study of the enzymes.

\section{Materials and Methods}

\subsection{Organisms and Materials}

Bacillus licheniformis F11.4 was kindly provided by the Indonesian government agency for assessment and application of technology (BPPT). The bacterial mutant is derived from $B$. licheniformis F.11, which was discovered during research collaboration between BPPT and Munster University-Germany under the Indo-German Biotechnology scheme. Collagen from snakehead fish skin was prepared according to Singh et al. (2011). Chemicals were purchased from Merck, Sigma, or Oxoid, through local distributors, except when specifically mentioned.

\subsection{Production and Partial Purification of Collagenases}

B. licheniformis F11.4 was grown in a medium containing $1 \% \mathrm{NaCl}, 0.5 \%$ tryptone, $0.25 \%$ yeast extract, and $5 \%$ collagen, for 24 hours at $37^{\circ} \mathrm{C}$ with agitation speed of $120 \mathrm{rpm}$. Collagenase secreted into the medium was harvested by cold centrifugation $\left(4^{\circ} \mathrm{C}\right)$ for 15 minutes at 7,500 g prior to ammonium sulphate precipitation at $50 \%$ saturation $(\mathrm{w} / \mathrm{v})$. The protein precipitate was dissolved in $0.02 \mathrm{M}$ phosphate buffer, pH 8.0, and dialyzed (MWCO $10 \mathrm{kDa}$ ) overnight against $0.01 \mathrm{M}$ phosphate buffer, $\mathrm{pH} 8.0$, at $4^{\circ} \mathrm{C}$. The dialyzed sample, designated as the crude enzyme, was applied to DEAE-Sepharose anion exchanger column (GE Healthcare Life Science, Pittsburg-PA, USA) that had previously been equilibrated with 0.02
M phosphate buffer, $\mathrm{pH}$ 8.0. The column was eluted with a gradient of $0-1 \mathrm{M} \mathrm{NaCl}$ in $0.02 \mathrm{M}$ phosphate buffer, $\mathrm{pH} 8.0$, at a flow rate of $0.5 \mathrm{ml} / \mathrm{min}$. The purification was performed on Äkta purifier system (GE Healthcare Life Science, Pittsburg-PA, USA) at room temperature $\left(25^{\circ} \mathrm{C}\right)$.

\subsection{CollagenaseAssay and Protein Concentration Determination}

Protease activity was measured using $5 \%$ collagen as the substrate (Bergmeyer et al. 1983). Briefly, $50 \mu \mathrm{l}$ of enzyme was mixed with $250 \mu$ l of substrate. The mixture was incubated for ten minutes at $37^{\circ} \mathrm{C}$. The enzymatic hydrolysis was stopped by addition of $1,250 \mu \mathrm{l}$ of $0.2 \mathrm{M}$ trichloroacetic acid (TCA), followed by cold centrifugation at 4,000 $\mathrm{g}$ for ten minutes. The supernatant was mixed with $0.4 \mathrm{M} \mathrm{Na}_{2} \mathrm{CO}_{3}$, followed by addition of Follin reagent at a ratio of $1: 2$. The mixture was further incubated at $37^{\circ} \mathrm{C}$ for 20 minutes. The amount of amino acid produced was measured at $578 \mathrm{~nm}$. One unit of enzyme activity $(\mathrm{U})$ is defined as the amount of enzyme required to produce $1 \mu \mathrm{mol}$ of amino acid per minute under specific conditions. Protein concentration was determined according to Bradford (1976) using bovine serum albumin (BSA) as the standard.

\subsection{SDS PAGE and Zymogram}

Molecular weight of proteins was estimated using SDS-PAGE (Laemmli 1970). Enzymes activity in situ was demonstrated in a zymogram gel (Choi et al. 2000), using $8 \%$ non-denaturing PA gel containing $0.1 \%(\mathrm{w} / \mathrm{v})$ collagen.

\subsection{Preparation of Bioactive Peptides Hydrolysate}

One $\mathrm{ml}$ of partially purified enzymes (0.4-0.7 $\mathrm{mg} / \mathrm{ml}$ ) was added into $50 \mathrm{ml}$ collagen solution $(0.5-1.0 \mathrm{mg} / \mathrm{ml})$ and mixed with $40 \mathrm{ml}$ phosphate buffer $500 \mathrm{mM}$. The mixture was incubated for 120 minutes at $40^{\circ} \mathrm{C}$. The enzymatic hydrolysis was stopped by an addition of $250 \mathrm{mM}$ TCA. The peptide solution was recovered after centrifugation at $4,000 \mathrm{~g}$ in $4^{\circ} \mathrm{C}$ and stored at $-20^{\circ} \mathrm{C}$. For inhibition studies, similar reaction was conducted at small scale (one tenth) in the presence of $20 \mu \mathrm{l}$ of 5 $\mathrm{mM}$ ethylenediaminetetraacetatic acid (EDTA) or phenylmethanesulfonylfluoride (PMSF).

\subsection{HMG-CoA Reductase Assay}

HMG-CoA reductase assay was performed according to Perchellet et al. 2009. Prior to the assay, 
a spectrophotometer was conditioned at $37^{\circ} \mathrm{C}$ and the measurement was carried out at $340 \mathrm{~nm}$ with and interval reading of 15 seconds for five minutes. The reaction mixture contained $5 \mu$ Pravastatin or peptides hydrolysate (the assay buffer as the blank), NADPH, HMG-CoA substrate, and HMGCoA Reductase (HMGR) (the assay buffer for the negative control and blank). The reaction mixture was thoroughly mixed prior to measurement in the spectrometer. The specific activity of enzyme was calculated according to the following equation:

Units $/ \mathrm{mgP}=\underline{(\Delta \mathrm{A} 340 / \mathrm{min} \text { sample }-\Delta \mathrm{A} 340 / \text { min blank }) \times \mathrm{TV})}$ $12.44 \times$ V x 0.6 x LP

Where:

$12.44: \varepsilon^{\mathrm{mM}}$-the extinction coefficient for NADPH at $340 \mathrm{~nm}$ is $6.22 \mathrm{mM}^{-1} \mathrm{~cm}^{-1} .12 .44$ represents the 2 NADPH consumed in the reaction

TV : total volume of the reaction in $\mathrm{ml}(\mathrm{ml})$

$\mathrm{V} \quad$ : volume of enzyme used $(\mathrm{ml})$

0.6 : enzyme concentration $(\mathrm{mg} / \mathrm{ml})$

LP : Light path in $\mathrm{cm}(1 \mathrm{~cm})$

One unit of enzyme is defined as the amount of enzyme required to convert one milli mole of NADPH to $\mathrm{NADP}^{+}$per minute at $37^{\circ} \mathrm{C}$.

\subsection{2,2-diphenyl-1-picrylhydrazyl (DPPH) Radical Scavenging Activity Assay}

The anti-oxidant measurement was performed according to Li et al. 2007. Briefly, $500 \mu$ of peptide solution was mixed with $500 \mu$ of $99.5 \%$ ethanol and $125 \mu \mathrm{l} 0.02 \% \mathrm{DPPH}$ in $99.5 \%$ ethanol. The mixture was kept in the dark for one hour at room temperature. Degradation of DPPH was measured at $517 \mathrm{~nm}$. Radical scavenging activity (RSA) was calculated as a percentage of the activity of the control (absence of antioxidant).

$$
\mathrm{RSA}=\frac{\text { Control }+(\text { Blank }- \text { sample })}{\text { Control }} \times 100 \%
$$

\section{Results}

\subsection{Partial Purification and Characterization of Collagenases}

Fractions collected during elution of DEAE anion exchanger column with $\mathrm{NaCl}$ at a gradient concentration of $0-1 \mathrm{M}$, showed the presence of at least seven collagenases (b1-b7) secreted by $B$. licheniformis F11.4 (Figure 1). SDS-PAGE present in Figure 1 shows that is $C$ is crude collagenase and $D$ is collagenase after ammonium sulphate addition. The collagenases were classified by means of protease inhibitors such as, PMSF (superscript P) for serine protease and EDTA (superscript E) for metalloprotease (Figure 2).

Interestingly, the inhibition profile identified serine protease (b1), metallo-protease (b2), and neither of both (b3-b7). The zymography assay may indicate the presence of possible dimer, trimer, or other oligomeric enzyme states, which are undetectable in SDS PAGE under denaturing conditions. Further, b7 was discovered to actually contain likely two species, which are neither serine nor metallo-protease (fraction 27) and a serine protease (40 and 50). The latter was designated as fraction $\mathrm{F}$ while fractions $26-34$ were combined and designated as fraction $\mathrm{D}$. Henceforth, the collagenase samples used were addressed as the fraction $\mathrm{D}$ and $\mathrm{F}$. The b7 species (Figure 1) was probably a very small enzyme or an enzyme fragment that still contains the active site of collagenase. Unfortunately, this molecular information cannot yet be disclosed. Nevertheless, the characterization of partially purified enzyme indicated the presence of more than one collagenase with different characteristics.

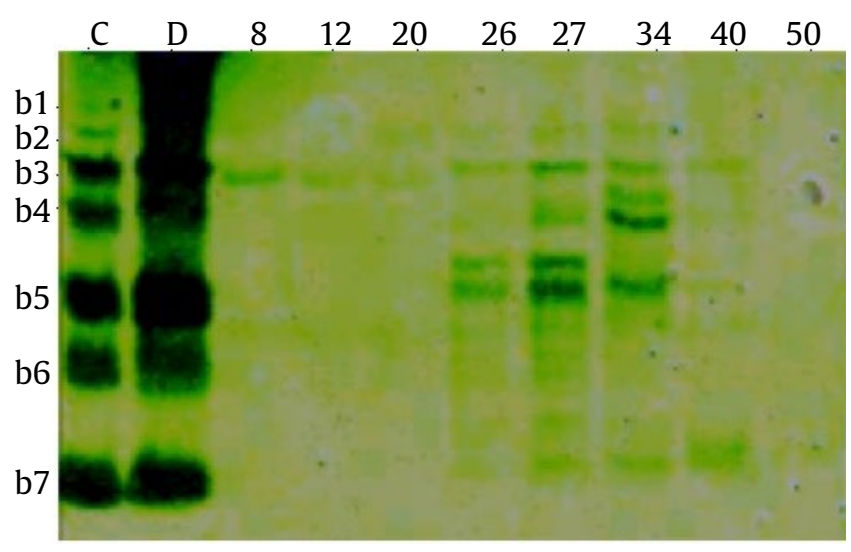

Figure 1.SDS-PAGE profile of the enzymes after purification with ammonium sulphate added and anion exchanger column. C: crude enzyme, D: after ammonium sulphate fractionation, 8-50 are fractions of enzymes 


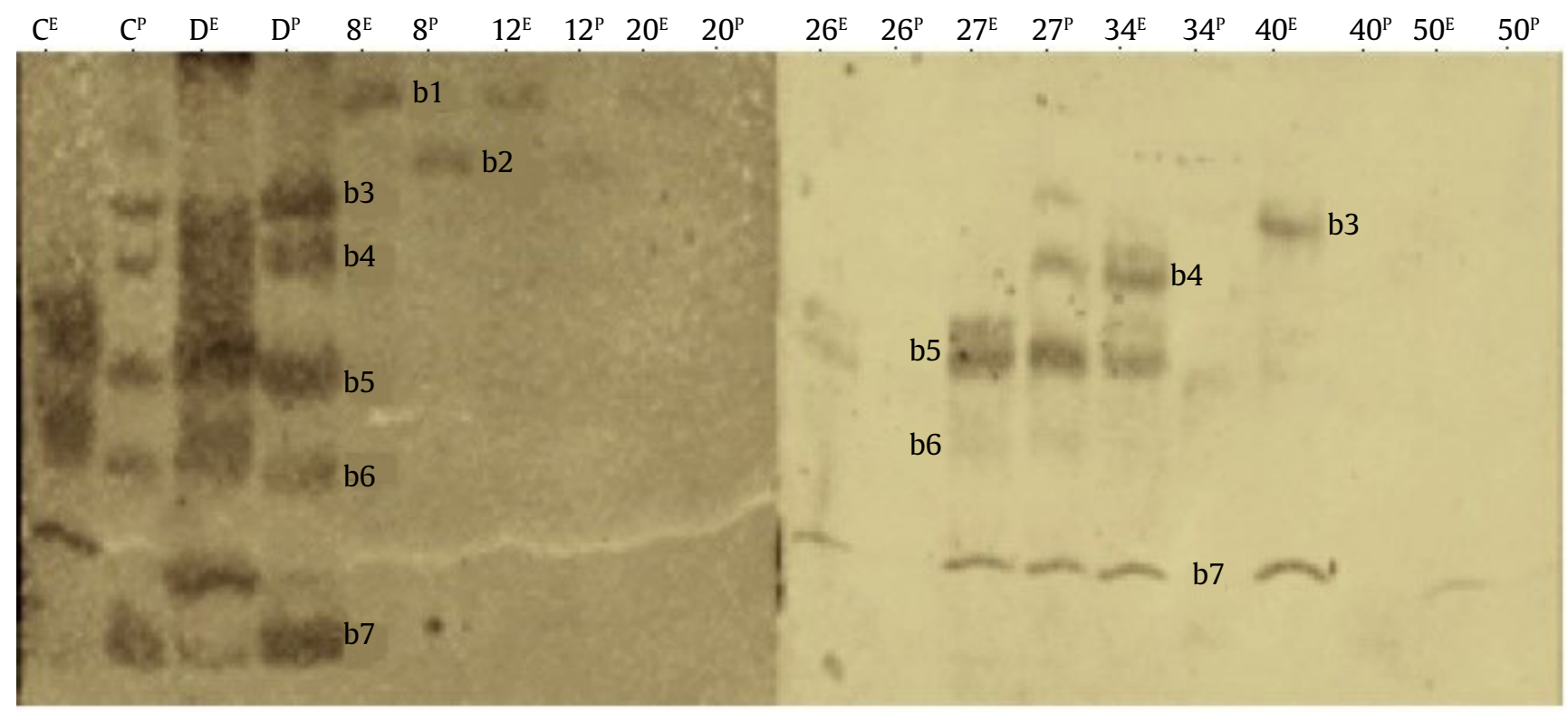

Figure 2. Zymography analysis of enzyme upon challenged with proteases inhibitors. C is crude enzyme, D is after ammonium sulphate fractionation, and 8-50 are fractions numbers of enzyme. Notation $\mathrm{E}$ and $\mathrm{P}$ (superscript) $\mathrm{S}$ refers to EDTA and PMSF, respectively

\subsection{Anti-cholesterol Activity}

Anti-cholesterol potential of the peptides hydrolysate generated from the snakehead skin collagen by the collagenases of $B$. licheniformis F11.4 was evaluated by means of inhibition of the activity of 3-hydroxy-3-methylglutaryl-coenzyme A reductase (HMGR) $(0.5-0.7 \mathrm{mgP} / \mathrm{ml})$ using the well-known anti-cholesterol drug pravastatin as the reference. Samples employed were collagen treated with enzymes of fraction $D$ or $F$ (in the presence and absence of $5 \mathrm{mM}$ PMSF or $5 \mathrm{mM}$ EDTA) and non-hydrolyzed snakehead skin collagen (for the basal activity). The result is presented in Figure 3. Interestingly, peptides hydrolysate generated by fraction $\mathrm{D}$ displayed similar inhibition power of HMGR activity to that of pravastatin. Further, treatment of fraction D with PMSF and/or EDTA brought down the inhibition to the basal level. On the other hand, peptides produced by fraction $\mathrm{F}$ demonstrated only 50\% inhibition to HMG-CoA activity in comparison to pravastatin. However, the activity of fraction $\mathrm{F}$ appeared to be sustained upon treatment by both EDTA and PMSF. Fraction $D$ is enigmatic because inhibition of one or few of its enzyme components by EDTA and/or PMSF resulted in impaired bioactive peptides production. Corresponding to the characteristics of collagenases

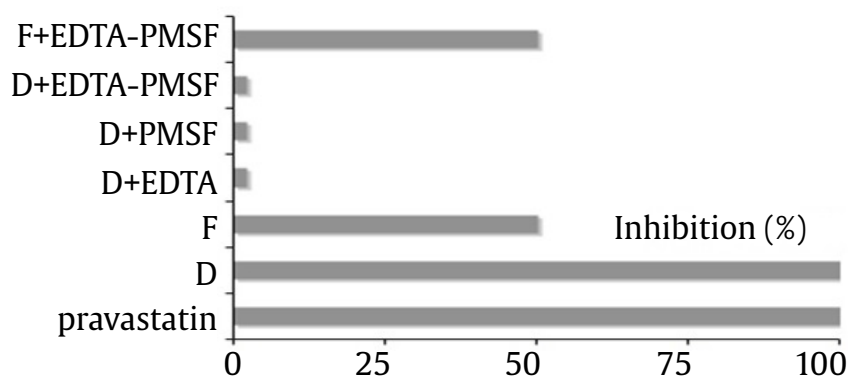

Figure 3. Inhibition of HMG-CoA reductase

in fraction $\mathrm{D}$, this result suggested that the bioactive peptides were produced by the mixture of serine and/or metallo-proteases, thus b1 and/or b2.

\subsection{Anti-oxidant Activity}

Anti-oxidant activity was evaluated by measuring reduction of DPPH. Vitamin C $(2 \mathrm{mM})$, vitamin $\mathrm{E}$ (2 $\mathrm{mM})$, and BHT $(2 \mathrm{mM})$ were employed as the references whilst non-hydrolyzed snakehead fish collagen as the basal. The result of radical scavenging challenge assay (Figure 4) suggested that the peptides hydrolysate generated by fractions $\mathrm{D}$ demonstrated no or negligible anti-oxidant activity, while peptides generated by fractions $F$ showed up to $10 \%$ scavenging activity. Interestingly, the mixture of peptides hydrolysate generated by mixture of fraction $\mathrm{D}$ and $\mathrm{F}$ showed up to $20 \%$ scavenging 


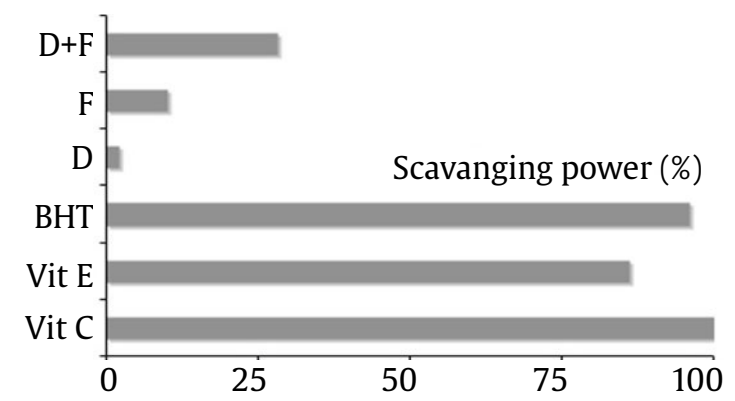

Figure 4. Antioxidant activity

activity. This suggests that components of the two enzyme fractions operate synergic.

\section{Discussion}

Snakehead fish (Channa striata) has been exploited for application in protein therapy, such as wound healing (Baie and Sheikh 2000). The skin of the fish contains high amount of proteins in a form of collagen $(17 \% \mathrm{w} / \mathrm{w})$ that can be used, for example, to prepare gelatin (See et al. 2010). The skin part is mostly discarded after the fish processing (Shahidi 1995), thus employing it as the collagen for generation of bioactive peptides is advantageous.

Peptides hydrolysate from snakehead fish skin collagen was generated through enzymatic hydrolysis using collagenases from $B$. licheniformis F11.4, a mutant of $B$. licheniformis 11 from Indonesia (Waldeck et al. 2006). Although SDS PAGE and zymography analysis were unable to clearly classify all collagenase fractions secreted, the inhibition study clearly shown the presence of serine-, metallo-, and neither of both types of proteases. The previous study using collagen from the skin of milkfish (Chanos chanos) indicated secretion of only two metallo-collagenases with apparent molecular weight of $26 \mathrm{kDa}$ and $124 \mathrm{kDa}$ (Baehaki et al. 2012; Baehaki et al. 2014). Unfortunately, this study could not clearly identify the molecular weight of each collagenase species because the various bands appeared in both SDS PAGE and zymography analysis but they are not entirely correlated. We could not yet exclude the presence of various oligomeric or even partial degradation forms of the enzymes. This issue would be solved in a peptide-mass finger printing analysis, which would be the next experiments to do. In particular, species b3 to b6 demonstrated similar bioactivity during the collagenase assay in situ, during which all were identified as neither serine nor metallo-protease. This finding is interesting because most of collagenases from Bacillus are characterized as metallo-protease (Liu et al. 2010; Baehaki et al. 2012; Baehaki et al. 2014), serine protease (Nagano and To 1999), or $\mathrm{Ca}^{2+}$-dependent and with disulfide bonds collagenase ( $\mathrm{Wu}$ et al. 2009). Also, the finding of species $F$ is very interesting because the enzyme is significantly smaller than the reported collagenases from other strains of Bacillus, e.g. from B. cereus MBL13 ( $38 \mathrm{kDa})$, B. circulans $(\sim 39 \mathrm{kDa})$, B. cereus Soc67 ( $\sim 88 \mathrm{kDa}), B$. cereus non-haemolytic enterotoxin (Nhe) ( $105 \mathrm{kDa})$, and B. substilis FS-2 ( $125 \mathrm{kDa})$ (Maäkinen and Maäkinen 1987; Lund and Granum 1999; Nagano and To 1999; Rao et al. 2008; Liu et al. 2010). This small enzyme species could have been a product of autolysis of the larger collagenase and still contains the active site (Vasilyeva 2002). Similar situation has been reported for an esterase from Emericella nidulans and Taralomyces emersonii $(\sim 1.6 \mathrm{kDa})$, which is called microenzyme (Fan and Mattey 1999). Further characterization of the enzyme in fraction $F$ would be very interesting for future application of microenzymes.

Fractions D and $\mathrm{F}$ were challenged to produce the snakehead fish skin collagen peptides hydrolysate for inhibition of HMGR activities and radical scavenging. HMGR is responsible for synthesis of mevalonate, and considered as the key enzyme for biosynthesis of cholesterol and other non-steroidal isoprenoid compounds (Arnaud 2005). Therefore, controlling the HMGR activity may lead to control the synthesis of cholesterol. Peptides hydrolysate produced by both fractions $\mathrm{D}$ and $\mathrm{F}$ demonstrated full and 50\% inhibition to HMGR activity, respectively. However, fraction $\mathrm{D}$ was unable to produce the peptides hydrolysate in the presence of EDTA and/or PMSF. On the other hands, fraction $F$ still hydrolyzed the collagen to produce bioactive peptides hydrolysate in the presence of the protease inhibitors. Combining the fractions $\mathrm{D}$ and $\mathrm{F}$ to produce bioactive peptides hydrolysate with anti-cholesterol functionality could be an intelligent option. This option may coincide with the finding of higher anti-oxidant activity of peptides hydrolysate recovered from hydrolysis of collagen by the combined fractions D and F. Thus, combined fractions $\mathrm{D}$ and $\mathrm{F}$ produced bioactive peptides hydrolysate with high anti-cholesterol activity accompanied by anti-oxidant activity, which leads to lower cholesterol level as well as prevention of radical formation in the blood. This 
circumstance would be ideal to combat development of cardiovascular diseases.

\section{Conflict of Interest}

The authors declare no conflict of interest on the publication of this article.

\section{Acknowledgements}

The research was supported by Ministry of Research and Technology, Republic of Indonesia, through funding incentive Sinas Research (Bioactive peptides as anti-hypertension and anti-cholesterol) and Dexa Laboratories of Biomolecular Sciences (DLBS). We thank Prof. F. Meinhardt from university of Münster and Dr. Siswa Setyahadi from BPPT for kindly providing the $B$. licheniformis F11.4.

\section{References}

Arnaud C et al. 2005. Cholesterol-independent effects of statins in inflammation, immunomodulation and atherosclerosis. Current Drug Target-Cardiovascular and Hematological Disorder 5:127-134.

Baehaki A et al. 2012. Purification and characterization of collagenase from Bacillus licheniformis F11.4. African J Microbiol Res 6:2373-2379.

Baehaki A et al. 2014. Production and characterization of collagenolytic protease from Bacillus licheniformis F11.4 originated from Indonesia. Asian JChem 26:2861-2864.

Baie SH, Sheikh KA. 2000. The wound healing properties of Channa striatus-cetrimide cream- tensile strength measurement. J Ethnopharmacol 71:93-100.

Bergmeyer HU et al. 1983. Methods of Enzymatic Analysis Vol. 2. Weinheim: Verlag Chemie.

Bradford MM. 1976. A rapid and sensitive method for the quantitation of microgram quantities of protein utilizing the principle of protein-dye binding. Anal Biochem 72:248-254.

Choi NS et al. 2000. Mixed-substrate (glycerol tributyrate and fibrin) zymography for simultaneous detection of lipolytic and proteolytic enzymes on a single gel. Electrophoresis 30:2234-2237.

Fan X, Mattey M. 1999. Small enzymes with esterase activities from two thermophilic fungi, Emericella nidulans and Taralomyces emersonii. Biotechnol let 21:1071-1076.

Gálvez AF. 2012. Abstract 10693:Identification of lunasin as the active component in soy protein responsible for reducing LDL cholesterol and risk of cardiovascular disease. Circulation 126:A1069.

Gálvez AF, de Lumen BO. 1999. A soybean cDNA encoding a chromatin binding peptide inhibits mitosis of mammalian cells. Nat Biotechnol 17:495-500.

Korhonen H, Pihlanto-Leppala A. 2003. Food-derived bioactive peptides: opportunities for designing future foods. Curr Pharm Des 9:1297-1308.
Korhonen H, Pihlanto-Leppala A. 2006. Bioactive peptides: production and functionality. Int Dairy J 16:945-960.

Kullisaar T et al. 2006. Antioxidative probiotic fermented goats milk decreases oxidative stress mediated atherogenicity in human subjects. BritJ Nutr 2:449-456.

Laemmli UK. 1970. Cleavage of structural proteins during the assembly of the head of bacteriophage T4. Nature 227:680-685.

Li B et al. 2007. Isolation and identification of antioxidative peptides from porcine collagen hydrolysate by consecutive chromatography and electrospray ionization-mass spectrometry. Food Chem 102:11351143.

Liu Let al. 2010. Purification and properties of a collagenolytic protease produced by Bacillus cereus MBL13 strain. Food Technol Biotechnol 48:151-160.

Lund T, Granum PE. 1999. The 105-kDa protein component of Bacillus cereus non-haemolytic enterotoxin (Nhe) is a metallo-protease with gelatinolytic and collagenolytic activity. FEMS Microbiol Lett 178:355-361.

Maäkinen KK, Maäkinen PL. 1987. Purification and properties of an extracelluar collagenolytic protease produced by the human oral bacterium Bacillus cereus (strain Soc 67). J Biol Chem 262:12488-12495.

Nagano H, To KA. 1999. Purification of collagenase and specificity of its related enzyme from Bacillus subtilis FS-2. Biosci Biotechnol Biochem 64:181-183.

Perchellet Jean-Pierre et al. 2009. Novel synthetics inhibitors of 3-hydroxy-3-methylglutaryl-coenzyme A(HMG-CoA) reductase activity that inhibit tumor cell proliferation and are structurally unrelated to existing statin. Int $J$ Mol Med 24:633-643.

Rao CS et al. 2008. Characterization of thermo- and detergent stable serine protease from isolated Bacillus circulans and evaluation of eco-friendly applications. Process Biochem 44:262- 268.

Rival SG et al. 2001. Caseins and casein hydrolysates. 2. Antioxidative properties and relevance to lipoxygenase inhibition. J Agric Food Chem 49:295-302.

See SF et al. 2010. Physicochemical properties of gelatins extracted from skins of different freshwater fish species. Int Food Res J 17:809-816.

Senevirathne M, Kim SK. 2012. Development of bioactive peptides from fish proteins and their health promoting ability. Adv Food Nutr Res 65:235-248.

Shahidi F. 1995. Proteins from seafood processing discards, pp. 171-193. In Shahidi F, Sikorski ZE, Sun Pan B (Eds.). Seafood Proteins. New York: Chapman and Hall.

Singh P et al. 2011. Isolation and characterisation of collagen extracted from the skin of striped catfish (Pangasianodon hypophthalmus). J Food Chem 124:97-105.

Vasilyeva OV et al. 2002. Domain structure and ATP-induced conformational changes in Escherichia coli protease Lon revealed by proteolysis and autolysis. FEBS Lett 526:66-70.

Waldeck Jet al. 2006. Isolation and molecular characterization of chitinase-deficient Bacillus licheniformis strains capable of deproteinization of shrimp shell waste to obtain highly viscous chitin. Appl Environ Microbiol 72:7879-7885.

Wu Q et al. 2009. Purification and characterization of a novel collagenase from Bacillus pumilus Col-J. Appl Biochem Biotechnol 160:129-139. 